\title{
TEKNOLOGI GELATINISASI PADA PAKAN SUMBER ENERGI DAN SUPLEMENTASI ASAM AMINO SEBAGAI UPAYA OPTIMALISASI PERTUMBUHAN TERNAK RUMINANSIA
}

\author{
GELATINIZATION OF FEED SOURCE OF ENERGY AND AMINO ACID \\ SUPPLEMENTATIO IN RATION TO OPTIMIZE OF GROWING SHEEP
}

\author{
Susi Dwi Widyawati \\ Jurusan Peternakan, Fakultas Pertanian UNS
}

\begin{abstract}
ABSTRAK
Penelitian yang bertujuan untuk mengetahui pengaruh gelatinisasi bahan pakan sumber energi dengan cara pengukusan (steaming) dan penggunaannya dalam ransum dalam upaya perbaikan performan domba, telah dilakukan di kandang percobaan Jatikuwung, Jurusan Peternakan UNS selama 4 (empat) bulan, mulai dari bulan Juni sampai dengan September 2009. Analisis bahan pakan percobaan dikerjakan di Laboratorium Ilmu Nutrisi dan Makanan Ternak, Fakultas Pertanian UNS.

Dua puluh ekor domba jantan dengan bobot badan individual berkisar antara $10 \pm 0.4 \mathrm{~kg}$, dibagi secara acak kedalam 6 perlakuan ransum. Ransum percobaan terdiri atas rumput raja dan konsentrat dengan perbandingan $=60: 40$ (dasar BK). Perlakuan yang diterapkan adalah P1:dedak padi, P2:dedak padi kukus, P3:dedak padi kukus +MHA, P4:Onggok, P5:Onggok kukus dan P6:Onggok kukus \pm MHA. Setiap perlakuan diulang 4 kali dan setiap ulangan terdiri dari satu ekor domba. Anova digunakan untuk mengetahui pengaruh perlakuan terhadap peubah yang diamati dan uji DMRT untuk uji beda nyata antar perlakuan.

Hasil penelitian menunjukkan bahwa pengukusan dan suplementasi MHA tidak mempengaruhi konsumsi ransum, PBBH dan konversi ransum, keadaan ini memberikan gambaran bahwa perlakuan yang diterapkan belum dapat memperbaiki konsumsi yang berakibat pada $\mathrm{PBBH}$, walaupun terdapat kecenderungan peningkatan pada konsumsi dan PBBH terutama pada dedak padi. Namun konsumsi protein nyata $(\mathrm{P}<0.05)$ dipengaruhi oleh perlakuan. Dedak padi dalam ransum memberikan konsumsi protein yang lebih tinggi $(\mathrm{P}<0.05)$ dibandingkan onggok. Penurunan konsumsi protein secara nyata $(\mathrm{P}<0.05)$ diikuti dengan kecenderungan $\mathrm{PBBH}$, hal ini menunjukkan adanya perbaikan kualitas protein dengan pengukusan dan suplementasi MHA sehingga terdapat pula kecenderungan peninglatan efisiensi penggunaan protein ransum.

Pengukusan dedak padi dan suplementasi MHA serta penggunaannya dalam ransum memberikan pengaruh yang baik pada pertumbuhan dan kualitas protein ransum domba.
\end{abstract}

Kata kunci : domba, gelatinisasi, dedak padi, onggok, MHA, performan

\section{ABSTRACT}

The study aimed to determine the effect of gelatinisation of feed ingredients as a energy sources by steaming and amino acid supplementation and its use in rations of sheep on performance improvements, has been done in the cage experiment Jatikuwung, Department of Animal Husbandry UNS for 4 (four) months, starting from June until September 2009. Analysis of feed materials is done in laboratory of Nutrition and Feed Science, Faculty of Agriculture UNS. Twenty sheeps with the initial's body weight ranged from $10+0.4 \mathrm{~kg}$, were divided randomly into 6 treatments. The rations consisted of king grass and concentrate with the ratio $=60: 40$ (DM basis). Treatment applied is P1: rice bran, P2: steamed rice bran, P3: steamed rice bran $+M H A$, P4: Onggok, P5: Onggok steamed and Q6: Onggok steamed + MHA. Each treatment is repeated 4 times and each test consisted of one sheep. Anova is used to determine the effect of treatment variables were observed and DMRT to test the real difference between treatments. The results showed that steaming and MHA supplementation did not affect the consumption of rations, ADG and FCR, this situation illustrates that the treatment can not be applied to improve the consumption, resulting in an $\mathrm{PBBH}$, although there is a tendency to increase consumption and 
$P B B H$ especially in rice bran. But the real protein consumption $(P<0.05)$ influenced by treatment. The protein consumption is higher of Rice bran $(P<0.05)$ compared onggok. Decrease in protein consumption significantly $(P<0.05)$ followed by $P B B H$ trend, this shows an improvement of protein quality steaming and supplemented with MHA so that there is also a tendency increase protein efficiency ration. Steaming rice bran and supplemented MHA and its use in rations provide a good influence on growth and protein quality of sheep rations.

Key words: sheep, gelatinisasi, rice bran, onggok, MHA, performance

\section{PENDAHULUAN}

Peternakan rakyat mempunyai kontribusi yang cukup besar dalam penyediaan sumber protein hewani bagi masyarakat Indonesia, sehingga produktivitas ternak khususnya ruminansia perlu ditingkatkan mencukupi kebutuhan daging. Produktivitas ternak tidak terlepas dari manajemen pemberian pakan.Jenis pakan yang diberikan ternak ruminansia berbeda dengan ternak unggas karena ruminansia cenderung membutuhkan jenis pakan berserat hal ini berhubungan dengan lambung majemuk yang dimilikinya, khususnya di retikulorumen yang dihuni oleh berjutajuta mikrobia yang berfungsi pada proses pencernaan fermentatif. Proses ini akan menghasilkan produk yang dimanfaatkan oleh induk semangnya. Namun optimalisasi pertumbuhan ternak masih memungkinkan untuk ditingkatkan dengan memanipulasi kondisi dalam rumen dan sentuhan teknologi pakan dalam meningkatkan efisiensi penggunaan ransum oleh ternak. Salah satu upaya yang dapat ditempuh dengan menyediakan nutrien yang dibutuhkan oleh mikrobia. Mikrobia sebagai sumber pakan yang berkualitas di pasca rumen cukup memberikan kontribusi bagi pertumbuhan induk semang (host)nya. Oleh sebab itu untuk meningkatkan produksi ternak dua aspek harus ditingkatkan yaitu fermentabilitas pakan dan pertumbuhan mikrobia rumen.

Dedak padi dan onggok merupakan bahan pakan sumber energi yang cukup potensial bagi ternak dengan kandungan nutrien yang cukup baik dan ketersediaan dilapangan yang cukup prospektif dan kontinyuitasnya yang masih bisa dipertahankan bagi ternak ruminansia. Untuk meningkatkan nilai efisiensi penggunaan nutrien pakan bagi ternak perlu sentuhan teknologi yang memadai.

Gelatinisasi yang secara prinsip diharapkan dapat melapisi bahan pakan tersebut, sehingga pada proses pencernaan oleh ternak ruminansia akan terhindar dari perombakan oleh mikrobia rumen selanjutnya akan terpecah di usus halus oleh enzim pencernaan dan menyediakan nutrien bagi induk semangnya. Proses pemasakan atau pengukusan yang didasarkan pada peningkatan suhu akibat penambahan uap air panas akan memecah ikatan-ikatan kimia dan menyebabkan berbagai tingkat degradasi yang meningkatkan kecernaan (Agus, 1999). Manik, 1995) menjelaskan bahwa onggok yang dikukus ditambah urea lebih baik dibandingkan yang dikukus ditinjau dari peningkatan kecernaan nutrien (TDN), fermentasi oleh mikrobia rumen, penghematan penggunaan nitrogen/protein (protein sparing effect), glukoneogenesis dan retensi $\mathrm{N}$ nya.

Penyediaan unsur $\mathrm{C}, \mathrm{N}$ dan $\mathrm{S}$ dalam kondisi berimbang dan tersedia secara bersamaan akan mampu meningkatkan sintesis mikrobia rumen secara optimal.. Ternak yang mendapatkan pakan basal berserat kasar tinggi, produksi mikroba dalam rumen dibatasi oleh ketersediaan energi, protein mudah larut dan mineral terutama S dan P (Chuzaemi, 1994). Sauvant et al, (1997), Widyobroto (1992) melaporkan bahwa sintesis protein mikroba akan optimal bila pelepasan prekursor $\mathrm{N}$ dan kerangka karbon di rumen yang dibutuhkan oleh mikroba selaras/sinkron.

Beberapa pertimbangan di atas digunakan sebagai landasan dalam penelitian ini dengan tujuan untuk mengetahui seberapa besar pengaruh gelatinisasi melalui pengukusan terhadap bahan pakan sumber energi dan penambahan sumber sulfur dari asam amino metionin (MHA= Methionine Hydroxy Analog) terhadap performan ternak.

\section{METODOLOGI PENELITIAN}

Penelitian ini akan dilaksanakan di Kandang Percobaan Jatikuwung Jurusan Peternakan Fakultas Pertanian UNS. Penelitian berlangsung selama 4 (empat) bulan dari bulan Juni sampai dengan September 2009. Analisis bahan percobaan dikerjakan di Laboratorium Ilmu Nutrisi dan Makanan Ternak, Jurusan Peternakan Fakultas Pertanian UNS menurut 
petunjuk AOAC (1980) dengan metode analisis proksimat.

Penelitian ini mengginakan domba lepas sapih dengan rataan bobot badan $11 \mathrm{~kg}$ sebanyak 24 ekor. Domba dibagi secara acak kedalam 6 perlakuan ransum, setiap perlakuan diulang 3 kali. Pemberian ransum didasarkan pada kebituhan bahan kering (BK) sebanyak 6\% dari bobot badan. Ransum terdiri atas hijauan yaitu rumput lapang dan konsentrat (dedak padi atau onggok) dengan perbandingan sebesar 60\% : $40 \%$.

Ransum percobaan yang menggunakan dedak padi dan onggok berturut-turut mengandung PK : 11.10\% dan 9.09\% dengan kandungan TDN masing-masing sebesar 50.61\% dan $50.14 \%$.

Dedak padi dan onggok yang digunakan berasal dari daerah Surakarta dan sekitarnya. Kandungan nutrien dan komposisi bahan pakan ransom perlakuan disajikan pada tabel 1 . Teknik pengukusan bahan pakan dedak padi dan onggok dilakukan dengan mengukus bahan pakan diatas air mendidih selama 60 menit hingga panasnya merata pada bahan pakan yang dikukus. Selanjutnya dikering udarakan dibawah sinar matahari sebelum diberikan pada ternak. Kandungan nutrien bahan pakan percobaan ditampilkan pada Tabel 1 dan komposisi bahan pakan ransum perlakuan disajikan pada Tabel 2.

MHA (Methyonine Hydroxy Analogue) sebagai suplemen asam amino esensial yang mengandung Sulfur (mineral $S$ ) yang dicampurkan dalam ransum sesuai perlakuan dengan jumlah pemberian 1 gram/ekor/hari.

\section{Peubah yang Diukur}

Pertumbuhan diukur dengan menimbang bobot badan ternak dalam kurun waktu tertentu. Pengukuran ini menunjukkan seberapa besar ransum yang dikonsumsi oleh ternak akan digunakan untuk mensintesis jaringan tubuhnya dengan imbangan $\mathrm{N}$ yang positif.

Penimbangan bobot badan dilakukan setiap 2 minggu sekali. Perhitungan pertambahan bobot badan dilakukan dengan mengurangi bobot badan akhir minggu dikurangi dengan bobot badan awal minggu yang bersangkutan. Konsumsi ransum (berdasarkan bahan kering) ransum diukur setiap hari dengan menghitung selisih antara jumlah ransum yang diberikan dikurangi dengan sisa ransum yang diperhitungkan dengan dasar BK. Efisiensi penggunaan ransum dihitung dengan membagi antara konsumsi ransum dan pertambahan bobot badan dalam sataun waktu yang sama. Nilai ini menunjukkan kemampuan ternak dalam mengkonversikan atau mengubah ransum menjadi bobot badan ternak. Tinggi rendahnya angka ini memberikan makna terhadap kualitas ransum yang diberikan. Semakin baik kualitas ransum yang diberikan akan memberikan angka konversi yang semakin kecil. Artinya untuk mewujudkan satu satuan bobot badan ternak hanya membutuhkan ransum yang sedikit. Konsumsi protein ransum diukur dengan menghitung konsumsi bahan kering ransum dikalikan dengan kadar protein ransum (dasar bahan kering). Nilai ini dihitung dengan membagi pertambahan bobot badan dengan konsumsi protein ransum. Angka ini untuk mengetahui pertambahan bobot badan dari satu unit protein.

\section{Analisis Data}

Data yang diperoleh dianalisis dengan analisis ragam untuk mengetahui pengaruh perlakuan terhadap peubah yang diamati. Jika terjadi pengaruh yang nyata dilanjutkan dengan uji jarak antar rataan perlakuan yaitu uji jarak Duncan's New Multiple Range Test (DMRT) mengikuti petunjuk Steel dan Torrie (1989).

Tabel 1. Kandungan Nutrien Bahan Pakan Perlakuan

\begin{tabular}{lccccccc}
\hline Bahan Pakan & BK & PK & LK & SK & BETN & Abu & TDN $^{*}$ \\
\hline Rumput Raja & 18.00 & 9.10 & 2.30 & 33.10 & 40.00 & 15.40 & 55.00 \\
Dedak padi & 90.75 & 11.54 & 14.68 & 11.06 & 55.74 & 6.98 & 80.05 \\
Onggok & 65.92 & 2.40 & 1.62 & 21.25 & 71.74 & 2.99 & 77.92 \\
\hline
\end{tabular}

Keterangan : ${ }^{*}$ estimasi TDN $=22.822-1.44(\mathrm{SK})-2.875(\mathrm{LK})+0.655(\mathrm{BETN})+0.863(\mathrm{PK})+0.020(\mathrm{SK})^{2}-$ $0.078(\mathrm{LK})^{2}+0.018(\mathrm{SK})(\mathrm{BETN})+0.045(\mathrm{LK})(\mathrm{BETN})-0.085(\mathrm{LK})(\mathrm{PK})+0.020(\mathrm{LK})^{2}(\mathrm{PK})($ Hartadi et al, 2005) 
Tabel 2. Komposisi Bahan Pakan Ransum Perlakuan

\begin{tabular}{lcccccc}
\hline Bahan pakan & DP & DPK & DPK+MHA & O & OK & OK+MHA \\
\hline Rumput Raja & 60 & 60 & 60 & 60 & 60 & 60 \\
Dedak padi & 31 & - & - & - & - & - \\
Onggok & - & - & - & 31 & - & - \\
Dedak padi kukus & - & 31 & 31 & - & - & - \\
Onggok kukus & - & - & - & - & 31 & 31 \\
Urea & 1 & 1 & 1 & 1 & 1 & 1 \\
Molases & 5 & 5 & 5 & 5 & 5 & 5 \\
MHA & - & - & 1 & - & - & 1 \\
Vitamin dan mineral & 2 & 2 & 2 & 2 & 2 & 2 \\
Minyak Sawit & 1 & 1 & 1 & 1 & 1 & 1 \\
J u m l a h & 100 & 100 & 101 & 100 & 100 & 101 \\
\hline
\end{tabular}

Keterangan: MHA, Methyonine Hydroxy Analogue

Tabel 3. Respon perlakuan terhadap performan domba

\begin{tabular}{lccccc}
\hline \multicolumn{1}{c}{ Perlakuan } & $\begin{array}{c}\text { Konsumsi } \\
\text { Ransum }\end{array}$ & PBBH & $\begin{array}{c}\text { Konversi } \\
\text { Ransum }\end{array}$ & $\begin{array}{c}\text { Konsumsi } \\
\text { Protein }\end{array}$ & EPPR \\
\hline Dedak Padi (DP) & 1258.69 & 51.53 & 25.10 & 385.70 & 0.13 \\
Dedak Padi Kukus (DPK) & 1075.11 & 58.16 & 19.65 & 329.45 & 0.18 \\
DPK + MHA & 1068.25 & 63.27 & 18.75 & 327.34 & 0.19 \\
Onggok (O) & 1007.52 & 50.51 & 23.40 & 260.88 & 0.17 \\
Onggok Kukus (OK) & 1175.46 & 57.65 & 23.55 & 304.36 & 0.07 \\
OK + MHA & 1149.98 & 54.59 & 24.32 & 291.60 & 0.04 \\
\hline
\end{tabular}

Keterangan : Nilai rataan yang bersuperskrip huruf kecil yang berbeda pada kolom yang sama menunjukkan adanya perbedaan yang nyata $(\mathrm{P}<0.05)$

\section{HASIL DAN PEMBAHASAN}

\section{Konsumsi Ransum}

Jumlah ransum yang dikonsumsi ternak dapat digunakan sebagai indikator palatabilitas ransum, selain itu akan menentukan banyaknya asupan nutrien bagi ternak untuk memenuhi kebutuhan hidup pokok maupun produksi. Banyaknya konsumsi ransum domba disajikan pada Tabel 3.

Banyaknya ransum yang dimakan oleh domba tidak dipengaruhi oleh perbedaan komposisi bahan pakan yang menyusun ransum percobaan. Pengukusan dedak padi dan onggok tidak menyebabkan adanya perbedaan konsumsi ransum yang nyata. Hasil penelitian ini berbeda dengan hasil penelitian yang telah dilaporkan oleh Soeharsono dkk., (2005) bahwa proses gelatinisasi dapat meningkatkan konsumsi ransum dan kecernaan protein sebagai akibat dari perbaikan pertumbuhan dan perkembangan mikrobia rumen sehingga fermentabilitas ransum meningkat serta kecernaan ransum meningkat, terutama kecernaan protein yang pada akhirnya akan merangsang ternak untuk mengkonsumsi ransom lebih banyak. Disamping itu, Manik (1985) menjelaskan bahwa pengukusan pada ubi kayu dapat meningkatkan konsumsi bahan kering ransum. Lebih lanjut dijelaskan bahwa peningkatan konsumsi bahan kering ransom disebabkan karena cukup tersedianya energi dan ubi kayu dikukus, dengan demikian aktivitas bakteri rumen meningkat, selanjutnya mengakibatkan lebih banyak bahan-bahan dari ransum yang dapat difermentasi dalam rumen. Faktor-faktor seperti densitas fisik pakan, ukuran partikel pakan, jumlah residu pakan tak tercerna, solubilitas bahan kering pakan, kecepatan fermentasi dalam rumen dan tingkat dan frekuaensi pemberian pakan akan berpengaruh terhadap rate of passage atau perjalanan pakan didalam saluras pencernaan (Church dan Pond, 1982). Selanjutnya dinyatakan bahwa kejadian yang selanjutnya bahwa keadaan tersebut akan mempengaruhi jumlah dan ruang lambung dan saluran pencernaan belakang terhadap pakan selanjutnya.

Hasil yang diperoleh dalam penelitian ini menunjukkan bahwa proses pengukusan dan teknik pengukusan yang berbeda dengan yang telah dikerjakan oleh peneliti sebelumnya, sehingga onggok maupun dedak padi yang dikukus dalam penelitian ini tidak mengakibatkan perbaikan palatabilitas ransum sebagai akibat dari peningkatan fermentabilitas onggok maupun dedak padi. Selain itu dapat dijelaskan bahwa onggok merupakan limbah industri atau bahan pakan inkonvensional sedangkan ubi kayu masih 
mengandung pati yang tinggi sehingga mampu menyediakan energi bagi ternak. Perbedaan kualitas bahan pakan yang dikukus juga mengakibatkan perbedaan hasil yang diperoleh dengan penelitian sebelumnya.

Konsumsi ransum ternak ruminansia dikontrol oleh faktor physiological demand karena kebutuhan untuk hidup pokok dan produksi di atas kapasitas lambungnya (NRC, 1987). Kapasitas lambung merupakan kontrol awal dari konsumsi ransum, pada saat kapasitas lambung penuh, maka ternak akan berhenti mengkonsumsi makanan walaupun kebutuhan nutrien belum terpenuhi. Faktor lainnya adalah kebutuhan nutrien yang tercermin dari densitas energi dan kecernaan ransum (Church dan Pond, 1982). Kemungkinan yang terjadi pada penelitian ini adalah bahwa ternak mengkonsumsi ransum sesuai dengan kapasitas lambungnya karena kebutuhan nutriennya belum terpenuhi, sehingga pengukusan yang dilakukan pada bahan pakan sumber enenrgi ini tidak terlihat pengaruhnya.

$$
\text { Ilustrasi di atas (Gambar1) }
$$

memperlihatkan kesetaraan jumlah ransum yang dikonsumsi oleh domba percobaan, walaupun terlihat adanya penurunan pada perlakuakn dedak padi namun pada perlakuan terhadap onggok terjadi peningkatan yang tidak nyata $(\mathrm{P}>0.05)$. Perlakuan pengukusan terhadap dedak padi dan onggok tidak mengakibatkan perubahan palatabilitas ransum. Disamping itu suplementasi MHA juga tidak memberikan efek yang berarti pada jumlah ransum yang dikonsumsi domba.

Suplementasi MHA (Methyonine Hydroxy Analogue) dalam ransum juga tidak mengakibatkan perbedaan yang nyata terhadap jumlah ransum yang dikonsumsi. Keadaan ini sesuai dengan pendapat Dilaga (1992) bahwa penggunaan MHA atau AHM (Analog Hidroksi Metionin) sampai dengan 8 gram (2 - 8 gram) per ekor per hari tidak mengubah konsumsi bahan kering ransum. Penggunaan MHA pada penelitian ini secara fisik tidak mengubah palatabilitas ransum, sehingga konsumsi berada pada kondisi yang normal sesuai dengan kebutuhan ternak.

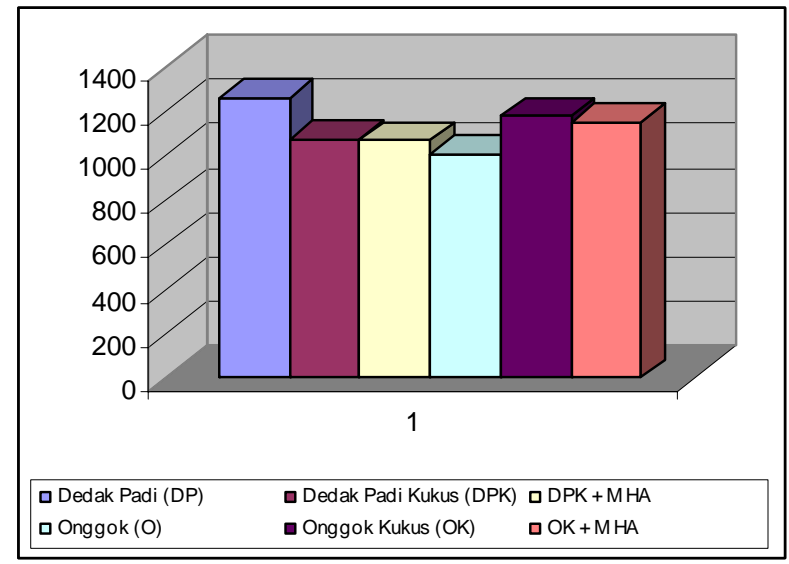

Gambar 1. Pengaruh perlakuan terhadap konsumsi ransum domba

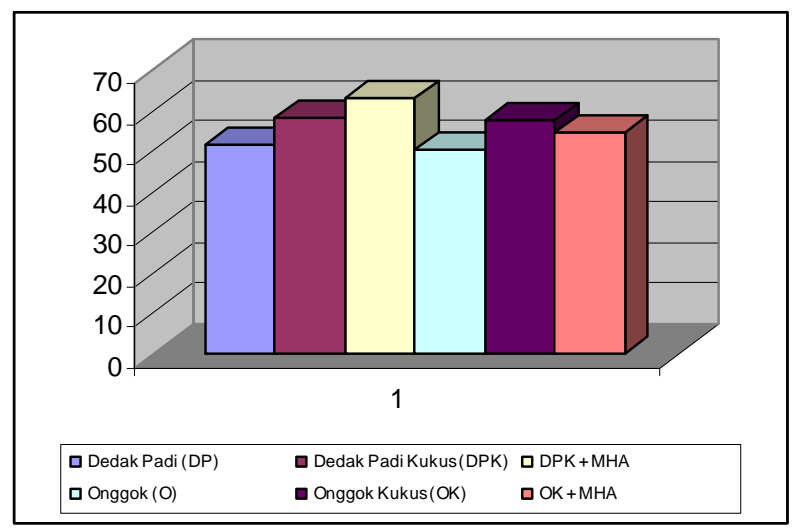

Gambar 2. Pengaruh perlakuan terhadap Pertambahan Bobot Badan Harian domba 


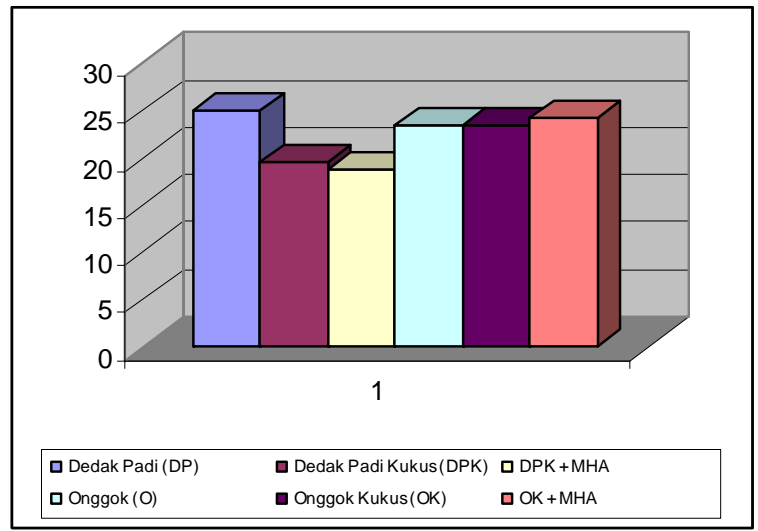

Gambar 3. Pengaruh perlakuan terhadap konversi ransum domba

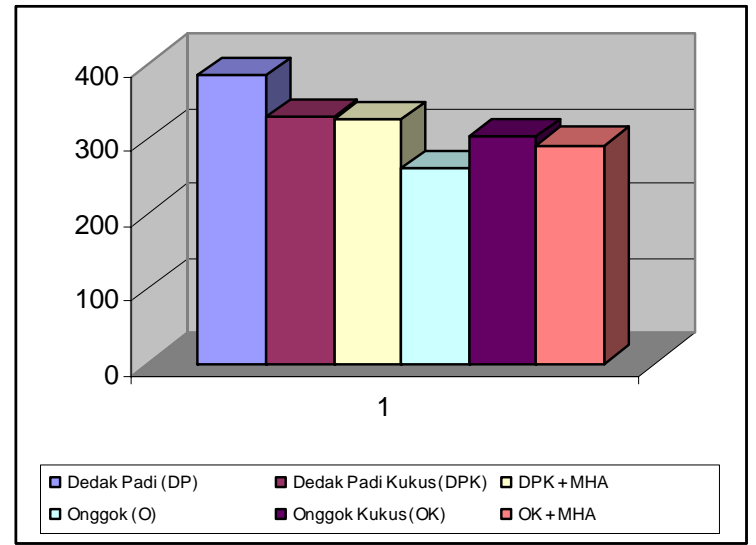

Gambar 4. Pengaruh perlakuan terhadap konsumsi protein ransum domba

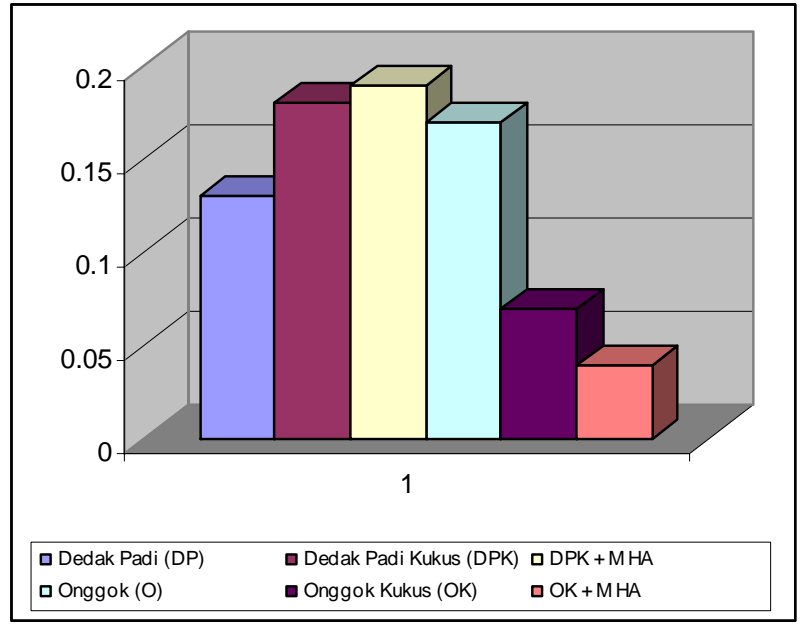

Gambar 5. Pengaruh perlakuan terhadap efisiensi penggunaan protein ransum 


\section{Pertambahan Bobot Badan}

Pertambahan bobot badan (PBB) merupakan ekspresi kualitas ransum yang diberikan pada ternak. Pemberian ransum yang disesuaikan dengan kebutuhan ternak baik kuantitas maupun kualitasnya akan memperlihatkan pertambahan bobot badan yang optimal.

Efek pengukusan dedak padi maupun onggok tidak memberikan perbaikan kualitas bahan pakan tersebut terlihat dari respon yang ditunjukkan pada peningkatan bobot badan domba yang tidak terlihat nyata. Telah dijelaskan di atas bahwa konsumsi ransum akan menentukan tingkat produksi ternak. Pertambahan bobot badan merupakan ekspresi dari kualitas ransum yang ditunjukkan denagn kandungan nutrien ransum. Tingkat konsumsi memberikan gambaran asupan nutrien bagi ternak tergantung pada densitas nutrien ransum tersebut. Hasil yang tidak berbeda nyata menunjukkan asupan nutrien yang setara antar perlakuan yang diterapkan dalam penelitian ini.

Namun jika dilihat dari ilustrsi di atas (Gambar 2), dengan sedikit penurunan konsumsi ransum akan meningkatkan pertambahan bobot badan domba pada perlakuan dedak padi kukus dan dengan suplementasi MHA. Keadaan ini tidak secara jelas terlihat pada perlakuan onggok kukus dan suplementasi MHA pada onggok kukus. Ini dapat dijelaskan adanya perbedaan kualitas dedak padi dan onggok. Dedak padi masih mengandung protein yang lebih tinggi dibandingkan dengan onggok (11.54\% vs $2.40 \%)$.

Dilaga (1992) melaporkan bahwa penggunaan AHM sebanyak 2 gram per ekor per hari memberikan efek terbaik terhadap penampilan, pertumbuhan dan produksi karkas anak sapi dibandingkan pemberian 4, 6 dan 8 gram per ekor per hari dalam ransum. Dari data yang diperoleh selama penelitian menunjukkan tidak adanya perbedaan yang nyata pada suplementasi MHA terhadap pertambahan bobot badan. Keadaan ini memberikan gambaran bahwa untuk terjadinya sintesis jaringan tubuh ternak membutuhkan nutrien yang cukup, seperti vitamin, mineral, protein dan energi. Suplementasi asam amino ini menjadi kurang efisien pemanfaatannya pada tubuh ternak, diduga karena tidak cukupnya asupan nutrien yang lainnya, sehingga proses metabolisme nutrien dalam tubuh ternak tidak terjadi secara optimal. Dari Gambar 2 terlihat adanya perbaikan yang lebih tinggi pada dedak padi dibandingkan dengan onggok. Hal ini terjadi karena asupan nutrien dari ransum yang mengandung dedak padi lebih baik dibandingkan asupan nutrien dari ransum yang mengandung onggok.

\section{Konversi Ransum}

Konversi ransum dihitung dengan membagi antara konsumsi ransum dan pertambahan bobot badan dalam sataun waktu yang sama. Nilai ini menunjukkan kemampuan ternak dalam mengkonversikan atau mengubah ransum menjadi bobot badan ternak. Tinggi rendahnya angka ini memberikan makna terhadap kualitas ransum yang diberikan. Semakin baik kualitas ransum yang diberikan akan memberikan angka konversi yang semakin kecil. Artinya untuk mewujudkan satu satuan bobot badan ternak hanya membutuhkan ransum yang sedikit.

Dari nilai matematis terlihat adanya penurunan konversi ransum pada perlakuan dedak padi dibandingkan onggok. Pada pemberian onggok, onggok kukus dan suplementasi MHA memberikan hasil yang tidak jauh bertbeda. Sedangkan pada perlakuan dedak padi, dedak padi kukus dan suplementasi MHA terlihat adanya kecenderungan perbaikan konversi ransumnya. Dari fakta yang ada, menunjukkan bahwa dedak padi mampu mensuplai nutrien yang lebih baik dari pada onggok. Dijelaskan oleh Soeharsono dkk., (2005) bahwa penggunaan gaplek-urea sebanyak 20\% mempunyai nilai yang lebih baik ditinjau dari nilai neraca nitrogennya. Nilai ini berkaitan dengan konsumsi dan kecernaan protein ransum.

Selain menunjukkan kualitas ransum, angka konversi juga dapat mencerminkan aspek ekonomi ditinjau dari efisiensi penggunaan ransum. Terlihat pada Gambar 3 bahwa angka konversi terendah pada penggunaan dedak padi kukus yang disuplementasi dengan MHA, dan ini jelas memberikan gambaran ransum yang paling ekonomis dibandingkan ransum yang lainnya, walaupun secara statistic menunjukkan adanya perbedaan yang tidak nyata.

\section{Konsumsi Protein Ransum}

Konsumsi protein ransum memberikan gambaran jumlah asupan protein untuk memenuhi kebutuhan protein bagi pertumbuhan optimal ternak domba. Hasil yang diperoleh dari penelitian ini disajikan pada tabel berikut.

Secara umum dapat dilihat pada tabel di atas bahwa konsumsi protein pada perlakuan dedak padi baik dikukus maupun disuplementasi dengan MHA lebih tinggi $(\mathrm{P}<0.05)$ konsumsi proteinnya dibandingkan dengan perlakuan onggok, onggok kukus dan suplementasi MHA dalam ransum domba. Pola yang ditunjukkan konsumsi protein ransum berbanding terbalik 
dengan pola pertambahan bobot badan domba. Hal ini disebabkan karena untuk menunjang pertambahan bobot badan dibutuhkan protein. Jika protein tidak tersedia secara cukup, maka pertambahan bobot badan ternak yang terjadi tidak optimal dan jika kelebihan akan dibuang melalui urin.

Gambar 2 dan 4 menunjukkan bahwa pada saat konsumsi protein rendah (pada perlakuan dedak padi) tetapi memberikan pertambahan bobot badan yang tinggi. Hal ini memberikan indikasi bahwa sejumlah protein yang dikonsumsi secara efisien dikonversikan menjadi bobot badan, Angka matematis, konsumsi protein ransum termasuk adanya suplementasi MHA menunjukkan adanya kecenderungan perbaikan performan domba percobaan.

Namun pada perlakuan onggok, onggok kukus dan suplementasi MHA tidak ada kecenderungan perbaikan performan domba. Keadaan ini kemungkinan disebabkan rendahnya kadar protein dalam onggok sehingga kurang mendukung sintesis jaringan tubuh domba maupun untuk sintesis protein mikrobial. Selain itu ketersediaan energi dan senyawa $\mathrm{N}\left(\mathrm{N}-\mathrm{NH}_{3}\right)$ yang tidak bersamaan, maka sintesis mikrobia rumen tidak akan optimal. Sebagaimana yang dinyatakan oleh Widyobroto, et al. (1999) bahwa sinkronisasi ketersediaan energi dan senyawa $\mathrm{N}$ dalam rumen diperlukan untuk terjadinya optimalisasi sintesis mikrobia rumen. Sekitar $82 \%$ dari total mikrobia rumen membutuhkan senyawa $\mathrm{N}$ dalam bentuk amonia atau $\mathrm{N}-\mathrm{NH}_{3}$ (Sutardi, 1978), kebutuhan energinya disediakan oleh karbohidrat yang mudah terfermentasi dalam rumen.

\section{Efisiensi Penggunaan Protein Ransum}

Nilai ini digunakan untuk mengevaluasi kualitas protein ransum. Namun pada ternak ruminansia, nilai ini tidak semata-mata cerminan dari kualitas protein ransum, karena pada ternak ruminansia protein yang masuk kedalam akan didegradasi oleh mikrobia rumen menghasilkan amonia $\left(\mathrm{N}-\mathrm{NH}_{3}\right)$ yang akan digunakan oleh mikrobia untuk tumbuh dan berkembang. Selain itu sumber protein bagi ternak berasal dari 2 (dua) sumber yaitu dari protein ransum (bypass protein) dan protein mikrobial.

Efisiensi penggunaan protein ini disajikan sebagai gambaran protein ransum yang masuk kedalam tubuh ternak dapat digunakan untuk membentuk bobot badan ternak. Perlakuan yang diterapkan dalam penelitian ini tidak memberikan pengaruh yang nyata terhadap efisiensi penggunaan ransum domba. Hal ini dapat dijelaskan bahwa terdapat perbedaan yang tidak nyata pada efisiensi penggunaan protein ransum. Keenam ransum perlakuan mempunyai nilai yang tidak berbeda satu sama lain dalam memanfaatkan protein ransum untuk membentuk bobot badan.

Gambar 5 menunjukkan bahwa terdapat kecenderungan ransum yang paling efisien menggunakan protein ransum adalah ransum yang mengandung dedak padi kukus yang disuplementasi dengan MHA.

\section{KESIMPULAN}

Kesimpulan yang dapat diambil dari penelitian ini bahwa penggunaan dedak padi kukus yang disuplementasi dengan MHA memberikan performan domba yang baik dengan angka konversi yang rendah.

\section{SARAN}

Teknologi gelatinisasi yang dilakukan dengan metode pengukusan atau steaming pada bahan pakan sumber karbohidrat pada suhu yang tepat sehingga dapat memperbaiki nilai nutrisi bahan pakan sumber energi ditinjau dari fermentabilitasnya dalam rumen.

\section{UCAPAN TERIMAKASIH}

Ucapan terima kasih disampaiakn kepada yang terhormat DIPA BLU selaku pemberi dana pada penelitian ini hingga penyusunan laporan ini.

\section{DAFTAR PUSTAKA}

Association of Official Analysis Chemist. 1980. Official methods of analysis of the Association of Official Analytical Chemist. 13th ed. Association of Official Analytical Chemist, Washington, DC.

Church, D.C. and W.G. Pond. 1982. Basic Animal Nutrition and Feeding. John Wiley \& Sons. New York.

Hartadi, H., S. Reksohadiprodjo, A.D. Tillman. 2005. Tabel Komposisi Pakan Untuk Indonesia. Gadjah Mada University Press.

Manik, I.G. 1985. Pengaruh Pengukusan Ubi Kayu Dalam Campuran Dengan Urea Sebagai Ransum Penguat Terhadap Metabolisme Glukosa, Nitrogen Dan Energi Pada Kambing Menyusui Dan Tidak Menyusui. Disertasi Bidang Keahlian Biologi, Fakultas Pasca Sarjana, IPB Bogor. 
McDonald, P., R.A. Edward and J.F.D. Greenhalgh. 1988. Animal Nutrition. $4^{\text {th }}$ edition. English Language Book Society, Longman, London.

National Research Council. 1987. Predicting Feed Intake of Food-Producing Animals. National Academic Press. Washington, D.C.

Sauvant, D and J. Van Milgen. 1995. Dynamic aspects of carbohydrate and protein breakdown and the associated microbial matter synthesis. In : Ruminant Physiology : Digestion, Metabolism, Growth and Reproduction (Engelhardt et al, Ed). Proceedings of the eight International Symposium on Ruminant Physiology. Stuttgart Germany. 71-87.

Soeharsono, Supriadi Dan E. Winarti. 2005. Pengaruh Pemberian Tepung Gaplek-Urea yang Dikukus Terhadap Konsumsi dan Kecernaan Protein Serta Neraca Nitrogen Pada Domba. Prosiding Seminar Nasional Teknologi Peternakan dan Veteriner, 2005, hal. 400-404.

Steel, R.G.D. dan J.H. Torrie.1989. Prinsip Dan Prosedur Statistika. Suatu Pendekatan Biometrik. Edisi Kedua. PT. Gramedia, Jakarta.

Sunarso. 1984. Mutu Protein Limbah Agro_Industri Ditinjau Dari Kinbetika
Perombakannya Oleh Mikrobia Rumen Dan Potensinya Dalam Menyediakan Protein Bagi Pencernaan Pasca Rumen. Thesis. Fakultas Pasca Sarjana, IPB. Bogor.

Sutardi, T. 1978. Ikhtisar Ruminologi. Dept. Ilmu Makanan Ternak, Fakultas Peternakan IPB. Bogor.

Widyobroto B.P., S. Padmowijoto, dan R. Utomo. 1997 Pendugaan kualitas protein 60 bahan pakan untuk ternak ruminansia. Laporan Penelitian. Fakultas Peternakan UGM, Yogyakarta.

Widyobroto B.P. 1998. Transit Partikel dan Cairan dalam Saluran Pencernaan Sapi Perah Produksi Tinggi yang Mendapat Ransum dengan Aras Konsentrat Berbeda. Buletin Peternakan., Volume 22, Hal. 168178 Fakultas Peternakan UGM; ISSN : 0126-4400.

Widyobroto B.P. 1999. Pengaruh Tipe Karbohidrat dan Aras Undegraded Protein terhadap Konsumsi, Kecernaan Nutrien dan Parameter Fermentasi Rumen Sapi Peranakan Friesian Holstein, Buletin Sintesis Nomor : 11 Tahun VII, Agustus 1999, Hal. 1-8 , Yayasan Dharma Agrika Semarang. 